\title{
RUBRIEKEN
}

KRONIEK

\section{Bestuurders: onderbelicht, maar onder het vergrootglas ${ }^{*}$}

\author{
Marieke van Genugten \& Marlies Honingh
}

Het belang van besturen en bestuurders die met een brede, maatschappelijke blik tot besluitvorming komen, wordt in crises zoals de huidige goed zichtbaar (zie bijvoorbeeld NRC Handelsblad, 11 mei 2020). Het aantal besturen in het publieke domein is in de afgelopen decennia sterk toegenomen en het aantal rapporten met handreikingen voor effectief en goed bestuur daarmee ook. Een greep uit die handreikingen: besturen moeten 'een lastig gesprek' voeren (Commissie Halsema, 2013), 'weerwerk' organiseren (WRR, 2014), 'fit-and-proper' zijn (Autoriteit woningcorporaties, 2016), een zuivere rol invullen (ABDTOPconsult, 2017), 'praktisch goed bestuur' vormen (Nolen, 2019). Maar, waar is deze stroom van adviezen op gebaseerd en wat weten we eigenlijk over wat besturen vermogen?

\section{Besturen in allerlei soorten en maten}

Voordat we deze vragen kunnen beantwoorden, is het noodzakelijk om eerst een onderscheid te maken naar typen besturen. Een eerste categorie besturen treffen we op rijksniveau, waar we vanaf de jaren tachtig een toename van het aantal besturen constateren als gevolg van het op afstand zetten van taken door de rijksoverheid. Zoals het geval is geweest bij de verzelfstandiging van het Uitvoeringsinstituut Werknemersverzekeringen (UWV) in de vorm van een zelfstandig bestuursorgaan (ZBO), de verzelfstandiging van de Nederlandse Spoorwegen in de vorm van een naamloze vennootschap (NV), en de verzelfstandiging van rijksmusea in de vorm van overheidsstichtingen.

Een tweede categorie besturen zien we op het niveau van decentrale overheden, waar we een vergelijkbare ontwikkeling van verzelfstandiging waarnemen. Ook hier treffen we organisaties met een privaatrechtelijke grondslag, zoals in de afvalinzameling in de vorm van NV's en op het gebied van cultuur, bijvoorbeeld theaters, in de vorm van overheidsstichtingen. Publiekrechtelijke vormen van verzelfstandiging zijn intergemeentelijke samenwerkingsverbanden op basis van

* Dr. M.L. van Genugten is universitair docent bij de sectie Bestuurskunde van de Faculteit der Managementwetenschappen van de Radboud Universiteit.

Dr. M.E. Honingh is universitair hoofddocent bij de sectie Bestuurskunde van de Faculteit der Managementwetenschappen van de Radboud Universiteit. 
de Wet gemeenschappelijke regelingen. De bestuurders van deze openbare lichamen zijn in tegenstelling tot veel andere besturen geen professionals, maar lokale politici (veelal leden van colleges van burgemeester en wethouders).

Een derde categorie omvat de besturen in semipublieke sectoren als onderwijs, zorg en wonen. Binnen deze sectoren heeft een omslag plaatsgevonden van vrijwillige naar professionele besturen. ${ }^{1}$ Verenigingen zijn veelal omgevormd tot stichtingen en besturen werken nu voornamelijk met een two-tier model waarbinnen de bestuurlijke en toezichthoudende functie doorgaans organiek gescheiden zijn.

Op basis van deze driedeling wordt direct zichtbaar dat het ene bestuur het andere niet is, terwijl in de nationale en internationale literatuur, geïnspireerd door principes en ontwikkelingen in de private sector, voornamelijk algemene verwachtingen worden geformuleerd over wat besturen vermogen.

\section{Verwachtingen ten aanzien van besturen}

Een eerste verwachting ten aanzien van besturen van verzelfstandigde organisaties is dat zij een schakel vormen tussen de politiek die op afstand staat en deze organisaties (Van Thiel, 2015). Bestuurders van die organisaties krijgen de ruimte om te besturen, maar er zijn wel duidelijke lijnen tussen de politiek en de bestuurders via benoeming en beloning (Van Thiel, Van Genugten, \& Voorn, 2020) en via informatieverplichtingen en verantwoording (Van Thiel, 2015; Schillemans \& Bovens, 2018). Dit laatste herkennen we ook in semipublieke sectoren zoals de onderwijssector.

Een belangrijke interne functie van besturen is om interne checks and balances te bieden. Vanuit het deel van het bestuur dat bekleed is met de bestuurlijke taak, gaat het dan om checks and balances ten opzichte van het management van de organisatie, terwijl het vanuit het bestuur met de toezichthoudende taak gaat om checks and balances tussen de toezichthoudende functie en de bestuurlijke functie (Papenfuß, Van Genugten, De Kruijf, \& Van Thiel, 2018; Schillemans \& Bovens, 2018). In navolging van de literatuur over corporate governance wordt hierbij veel waarde gehecht aan governance codes. In deze codes worden de bestuurlijke en de toezichthoudende taken expliciet gemaakt en wordt ook stevig gehamerd op rolvastheid van bestuurders en toezichthouders.

Van besturen wordt ook verwacht dat zij de legitimiteit van de organisatie vergroten, indien zij een afspiegeling vormen van de samenleving in het algemeen en van relevante stakeholders in het bijzonder (vergelijk Carter, D’Souza, Simkins, \& Simpson, 2010). Een adequate afspiegeling van de samenleving en een mix van competenties zouden daarnaast kunnen bijdragen aan het inspelen op de wensen en belangen die in de samenleving leven en het toegerust zijn op de complexiteit

1 Openbare onderwijsinstellingen die aanvankelijk bestuurd werden door de gemeente, kregen in 1996 de mogelijkheid om te verzelfstandigen (Staatsblad 1996, 580). 
van de vraagstukken die in de samenleving spelen. Dit zou uiteindelijk de prestaties van de organisaties ten goede komen (vergelijk Carter et al., 2010).

In deze weergave zien we om te beginnen dat de verwachtingen lang niet altijd expliciet verwijzen naar toezichthoudende of bestuurlijke taken en tamelijk abstract en losjes worden geformuleerd. Ten tweede zien we een interessant patroon waarbij aan de ene kant argumenten worden aangedragen die te maken hebben met principes van goed bestuur, inbedding in de samenleving en verantwoording aan maatschappelijk relevante actoren. Aan de andere kant herkennen we een instrumenteel perspectief dat gericht is op het komen tot een hogere kwaliteit van diensten.

\section{Recente ontwikkelingen in het extern toezicht: bestuurders onder het vergrootglas}

Gelet op de hooggespannen verwachtingen verbaast het wellicht niet dat het extern toezicht bij semipublieke instellingen zich ontwikkelt in de richting van bestuursgericht toezicht. Binnen dit toezicht wordt een verbinding gelegd tussen bestuur van goede kwaliteit en het leveren van een hoge kwaliteit van diensten. Binnen het bestuursgericht toezicht (zie ook themanummer 2018/4; Honingh et al., te verschijnen) zetten inspecties bestuurders aan tot het werken aan kwaliteitsverbetering door hen aan te spreken op borging van kwaliteit en door na te gaan in hoeverre bestuurders zicht hebben op de kwaliteit van de diensten die geleverd worden. Daarmee proberen inspecties in hun toezicht meer aan te sluiten bij de binnen de instellingen bestaande kwaliteitszorg en het vermogen van de besturen (Bokhorst, Van Genugten, Oude-Vrielink, \& Schillemans, 2018).

Dit betekent onherroepelijk dat de aandacht in het extern toezicht zich nog sterker zal gaan richten op de besturen en hun verantwoordelijkheden. De premisses die hieraan ten grondslag liggen, bouwen voort op de verwachtingen die we hiervoor beschreven (Bokhorst et al., 2018). Bovendien worden bestuurders zowel in het extern als intern toezicht veel nadrukkelijker in persoon aangesproken. Nolen (2017) beschrijft dit wanneer hij spreekt over de juridische kwetsbaarheid van schoolbestuurders. Maar ook in andere sectoren zien we een vergelijkbare ontwikkeling via de 'fit and proper'-test. Deze test voor de geschiktheid en betrouwbaarheid van bestuurders en toezichthouders maakt bijvoorbeeld onderdeel uit van het bestuursgericht toezicht in de sector wonen. En zo komt ook hier de nadruk op de persoon van de bestuurder te liggen.

\section{Besturen onderbelicht}

Met het oog op de handreikingen en verwachtingen die we hiervoor noemden en de recente ontwikkelingen in het extern toezicht, komt de vraag op in hoeverre we zicht hebben op de mate waarin verwachtingen ten aanzien van verantwoording, goed bestuur, legitimiteit en kwaliteit van diensten in de praktijk van 
besturen waargemaakt (kunnen) worden. Alles overziend blijkt dat er relatief weinig empirisch onderzoek naar besturen in het publiek domein wordt gedaan. En het onderzoek dat er is, stemt vooralsnog weinig optimistisch.

Allereerst laat onderzoek zien dat besturen hun rol als verantwoordingsforum slechts beperkt waarmaken (Schillemans \& Bovens, 2018). Als het, ten tweede, gaat om goed bestuur (de interne checks and balances tussen toezicht, bestuur en management), stellen we vast dat vooral onderzoek wordt gedaan naar de adoptie en naleving van governance codes en in mindere mate naar de werking van die codes (Aguilera \& Cuervo-Cazurra, 2009). Juist dit laatste is van groot belang. Misstanden in de semipublieke sector laten immers zien dat checks and balances op papier in orde kunnen zijn, maar dat dit niet betekent dat die in de praktijk ook werken (Honingh \& Van Genugten, 2014; WRR, 2014). Van groot belang is het daarom meer zicht te krijgen op de dynamieken binnen besturen. 'Board dynamics' staat in onderzoek naar besturen in het publieke domein echter nog in de kinderschoenen (vergelijk Nielsen \& Huse, 2010). Ten derde wordt de vraag naar de betekenis van besturen voor de legitimiteit en kwaliteit van organisaties voor een deel gekoppeld aan de diversiteit van besturen en de mate waarin zij een adequate afspiegeling vormen van hun stakeholders en de samenleving in brede zin. Juist aan deze assumptie wordt in de praktijk slechts beperkt voldaan, omdat besturen vaak klein of zelfs eenhoofdig zijn (vgl. Honingh \& Van Genugten, 2014; Papenfuß et al., 2018). Daarnaast constateren we dat er een kennisleemte bestaat ten aanzien van de bijdrage van besturen aan de kwaliteit van diensten, zowel in de private als de publieke sector (vgl. Brown \& Guo, 2010; Honingh, Ruiter, \& Van Thiel, 2018; Stoker \& Garretsen, 2018).

Hiermee komen we tot een laatste punt. Waar in de praktijk een enorme variatie aan bestuursmodellen bestaat, blijkt dit veel minder het geval te zijn in de theorievorming over besturen en hun functioneren. De hypothesen over het functioneren van besturen in de literatuur zijn tamelijk algemeen geformuleerd en nauwelijks toegespitst op specifieke verhoudingen, bestuursmodellen en sectoren. De variabelen die doorgaans worden onderzocht, hebben betrekking op eigenaarschap, omvang en diversiteit van het bestuur (vgl. Howard \& Seth-Purdie, 2005; Adams \& Ferreira, 2009; Nielsen \& Huse, 2010; Cornforth, 2012). Maar het is zeer de vraag of deze variabelen ook daadwerkelijk de sleutelvariabelen zijn om beter zicht te krijgen op het vermogen van de besturen die we eerder onderscheidden.

Samenvattend laten de vragen die we hebben aangedragen zien dat het noodzakelijk is dat we de (beleids)theoretische aannamen ten aanzien van besturen in het publieke domein nog eens goed tegen het licht houden. Daarnaast maken de voorgaande vragen duidelijk dat het doorgronden van besturen en wat zij vermogen een klus is die meer precisie en onderzoek vereist. Juist nu toezichtbeleid voortbouwt op het idee dat besturen veel vermogen, is het hoog tijd om hiermee aan de slag te gaan! 


\section{Literatuur}

ABDTOPconsult. (2017). Verbeter de werking!! Rollen in de sturing van uitvoeringsorganisaties in de Rijksdienst. Den Haag: ABD.

Adams, R.B., \& Ferreira, D. (2009). Women in the boardroom and their impact on governance and performance. Journal of Financial Economics, 94(2), 291-309.

Aguilera, R.V., \& Cuervo-Cazurra, A. (2009). Codes of good governance. Corporate Governance, 17 (3), 376-387.

Autoriteit woningcorporaties. (2016). Contouren van het toezicht. Den Haag: ILT.

Bokhorst, M., Genugten, M. van, Oude-Vrielink, M., \& Schillemans, T. (2018). Van toezicht op kwaliteit naar toezicht op bestuur: Ontwikkelingen van bestuursgericht toezicht in semipublieke sectoren. Bestuurskunde, 27(4), 3-18.

Brown, W.A., \& Guo, C. (2010). Exploring the key roles for nonprofit boards. Nonprofit and Voluntary Sector Quarterly, 39(3), 536-546.

Carter, D., D’Souza, F., Simkins, B., \& Simpson, W. (2010). The gender and ethnic diversity of US boards and board committees and firm financial performance. Corporate Governance, 18 (5), 396-414.

Commissie Halsema. (2013). Een lastig gesprek. Den Haag: OCW.

Cornforth, C. (2012). Nonprofit governance research: Limitations of the focus on boards and suggestions for new directions. Nonprofit and Voluntary Sector Quarterly, 41(6), 1116-1135.

Honingh, M., Ehren, M., Montfort, C. van, Blom, R., Genugten, M. van, \& Gooyert, V. de. (te verschijnen). Effectstudie van het vernieuwde toezicht: Eindrapportage.

Honingh, M., \& Genugten, M. van. (2014). Monitorstudie Goed Onderwijsbestuur in het VO. Nijmegen: Institute of Management Research.

Honingh, M., Ruiter, M., \& Thiel, S. van. (2018). Are school boards and educational quality related? Results of an international literature review. Educational Review, https:// doi.org/10.1080/00131911.2018.1487387

Howard, C., \& Seth-Purdie, R. (2005). Governance issues for public sector boards. Australian Journal of Public Administration, 64(3), 56-68.

Nielsen, S., \& Huse, M. (2010). The contribution of women on boards of directors: Going beyond the surface. Corporate Governance, 18 (2), 136-148.

Nolen, M.F. (2017). De bestuurder in het onderwijs: De juridische positie van de bestuurder in vijf onderwijssectoren (dissertatie Vrije Universiteit). Amsterdam: Boom.

Nolen, M.F. (2019). Tijd om zelf te dansen. Delft.

NRC Handelsblad (2020, 11 mei). Crisis vergroot bestuurlijke relaties uit. p. 8.

Papenfuß, U., Genugten, M. van, Kruijf, J. de, \& Thiel, S. van. (2018). Implementation of EU initiatives on gender diversity and executive directors' pay in municipally-owned enterprises in Germany and the Netherlands. Public Money \& Management, 38(2), 87-96.

Schillemans, T., \& Bovens, M. (2018). Governance, accountability and the role of public sector boards. Policy \& Politics, 47(1), 187-206.

Stoker, J., \& Garretsen, H. (2018). Goede leiders zweven niet: De fundamenten van effectief leiderschap in organisaties en de maatschappij. Amsterdam/Antwerpen: Business Contact.

Thiel, S. van. (2015). Boards of public sector organizations: A typology with Dutch illustrations. International Journal of Public Sector Management, 28(4/5), 322-334.

Thiel, S. van, Genugten, M. van, \& Voorn, B. (2020). Principals and agents: The relationship between governments and state-owned enterprises. In L. Bernier, P. Bance, \& M. 
Marieke van Genugten \& Marlies Honingh

Florio (Eds.), The Routledge handbook of state-owned enterprises. Abingdon: Taylor \& Francis.

WRR. (2014). Van tweeluik naar driehoeken: Versterking van interne checks en balances bij semipublieke organisaties. Amsterdam: Amsterdam University Press. 